\title{
KÜLÖNBÖZÖ SACCHAROMYCES CEREVISIAE OLDATOK HATÁSA RUKKOLA VEGETATÍV NÖVEKEDÉSÉRE
}

\author{
Csambalik László - Tóbiás Andrea
}

\begin{abstract}
Absztrakt: Számos kísérlet vizsgálja a levélfelületre kijuttatott élesztő oldatok növények vegetatív fejlődését elősegítő hatását, jellemzően pozitív hatást megállapítva. Kísérletünkben olyan, az ökológiai gazdálkodás gyakorlatába is könnyen beilleszthető, S. cerevisiae szuszpenziók felhasználásán alapuló módszer kidolgozására törekedtünk, amely könnyen beilleszthető a kis- és közepes gazdaságok gyakorlatába, és amely mérhető termésnövekedéssel jár.
\end{abstract}

Egy nagyobb kutatás részeként, kereskedelmi forgalomban beszerezhető instant élesztő, illetve $S$. cerevisiae NCAIM Y.00801 törzsgyüjteményi típustörzs felhasználásával, két gyakorisággal és koncentrációban $(0,1$ és $1 \%$ v/v) elicitor oldatot juttattunk szabadföldön termesztett rukkola lombozatára. Kezelésenként és ismétlésenként 10-10 növényt gyüjtöttünk be a vetést követő hatodik héten. A betakarítás után lemért vegetatív paraméterek: növény friss tömeg, levéltömeg, levélszám, levélarány, maximum levélhossz, gyökértömeg, növény magasság, gyökérhossz, gyökérnyak átmérő. Eredményeink azt mutatták, hogy az alacsonyabb koncentráció kedvezőbb hatást gyakorolt elsősorban a nedves tömeg, levéltömeg, gyökérnyak átmérő és gyökértömeg esetében. A törzsgyüjteményi és instant élesztő között egyértelmủ különbséget nem találtunk.

\begin{abstract}
Several studies investigate the effect of the foliar application of yeast suspensions on vegetative development; the results generally show a positive impact. This study aims to develop a technology, which fits into the practice of organic farming, and which is based on the use of S. cerevisiae suspensions; it aims to be applicable in small- and middle scale farming, and provides measurable yield increase.
\end{abstract}

As a part of a broader study, elicitor suspensions were prepared with the use of commercially available instant yield and S. cerevisiae NCAIM Y.00801 strain in two concentrations $(0.1$ and $1 \% \mathrm{v} / \mathrm{v})$ and two frequencies (once, three times). Ten plants were collected on the seventh week after sowing. The measured vegetative parameters were: fresh weight, leaf weight, leaf number, leaf ratio, maximum leaf length, root weight, plant height, root length, root diameter. Results showed that lower concentrations had favorable impact mainly on fresh weight, plant weight, root diameter, and root weight. No clear difference were found between the effect of instant yeast and the applied strain.

Kulcsszavak: elicitor, ökológiai gazdálkodás, zöldtömeg

Keywords: elicitor, organic farming, green mass

\section{Bevezetés}

A növények vegetatív fejlödése, termésmennyisége és stressztürő képessége fokozható különböző biostimulánsok alkalmazásával (Hammad, 2008). Élesztő felhasználsával olyan biostimuláns készíthető, amely a fehérjéken, szénhidrátokon, nukleinsavakon, lipdeken és különböző ásványi anyagokon kívül növekedésszabályozó anyagokat (tiamin, riboflavin, piridoxin, niacin, B-vitaminok, citokininek) is tartalmaz (Barnett et al, 1990, Nagodawithana, 1991). Vegetatív fejlődésre gyakorolt pozitív hatását számos kultúrában igazolták (burgonya: Sarhan és Abdullah, 2010, Ahmed et al, 2011, paprika: Fathy és Farid, 1996, Ghoname et al, 2010, paradicsom: El-Desouky et al, 2011). Fejessaláta esetében, élesztő szuszpenziók alkalmazása után a levélszám és a száraztömeg növekedéséről számol 
be Fawzy (2010). Azonos eredményre jut Farrag et al. (2016) is. A vegetatív fejlödés serkenétésével a növények asszimiláló felülete megnövekszik, ami pozitív hatással lehet az asszimilátumok képződésére is (Zlotek és Swieca, 2016).

\section{Anyag és módszer}

A szabadföldi kísérlet a Szent István Egyetem Soroksári Kísérleti Üzem és Tangazdaságában, az Ökológiai Gazdálkodás Ágazatban került beállításra, 2017. öszén. A termesztés során ökológiai szaporítóanyagot alkalmaztunk. Egy parcella 25 növényt tartalmazott, egy kezelést 100 növény reprezentált. A kísérlet négy ismétlésben, blokk elrendezésben került beállításra.

Az oldatok elkészítési Gawlik-Dziki et al. (2013) módszere szerint történt a SZIE Élelmiszertudományi Kar Mezőgazdasági és Ipari Mikroorganizmusok Nemzeti Gyüjteményének laboratóriumában. A kezelések kontrollja desztillált víz volt. Az oldatok elkészítéséhez kereskedelmi forgalomban beszerezhető instant élesztőt (B), valamint törzsgyüjteményi élö tenyészetből származó S. cerevisiae NCAIM Y.00801 típustörzset (T) használtuk. A desztillált vízzel készített oldatokat száraz tömegre vonatkoztatva két koncentrációban $(0,1$ és $1 \% \mathrm{v} / \mathrm{v})$ állítottuk elö. A lombkezeléseket kézi szórófejjel végeztük el, egy növényre megközelítőleg $2 \mathrm{ml}$ oldat jutott. Egyszeri kezelés esetén a vetést követő negyedik héten, háromszori kezelés (3) esetén kéthetente történt a permetezés. A kezelések kódjai az alkalmazott koncentrációból, alapanyagból és gyakoriságból tevődtek össze (1. táblázat).

A vetést követő hetedik héten minden parcellából 10-10 növényt gyüjtöttünk be. A vegetatív paramétereket laboratóriumi mérleggel és digitális tolómérővel határoztuk meg. A minden növényegyed esetén mért paraméterek a növény friss tömeg, levéltömeg, levélszám, levélarány, maximum levélhossz, gyökértömeg, növény magasság, gyökérhossz és gyökérnyak átmérö volt. A levélarányt a tömegadatokból számoltuk.

A statisztikai vizsgálatok elvégzéséhez IBM SPSS Statistica 25 programcsomagot használtunk, többtényezős varianciaanalízist (MANOVA) végeztünk, a rezidumok normalitásától függően Games-Howell, vagy Tukey posthoc teszttel $(\mathrm{p}<0,05)$. A PCA bi-plotot PanelCheck programmal készítettük.

\section{1. táblázat: A kísérlet során alkalmazott kezelések jellemzői}

\begin{tabular}{llll} 
Kód & Alapanyag & $\begin{array}{l}\text { Koncentráció } \\
\%(\mathrm{v} / \mathrm{v})\end{array}$ & Gyakoriság \\
\hline $0,1 \mathrm{~B}$ & Instant élesztő & 0,1 & egyszer \\
$0,1 \mathrm{~B} 3$ & Instant élesztő & 0,1 & háromszor \\
$0,1 \mathrm{~T}$ & S. cerevisiae NCAIM Y.00801 & 0,1 & egyszer \\
$0,1 \mathrm{~T} 3$ & S. cerevisiae NCAIM Y.00801 & 0,1 & háromszor \\
1B & Instant élesztő & 1 & egyszer \\
1B3 & Instant élesztő & 1 & háromszor \\
1T & S. cerevisiae NCAIM Y.00801 & 1 & egyszer \\
1T3 & S. cerevisiae NCAIM Y.00801 & 1 & háromszor \\
K & Desztillált víz & - & háromszor \\
\hline
\end{tabular}




\section{Eredmények és értékelésük}

A rukkola növényen mért vegetatív paraméterek átlagértékeit és szignifikancia viszonyait a 2. táblázat ismerteti. A levélarányt kivéve minden esetben kaptunk szignifikáns különbségeket, de egyértelmüen a kontrolltól nem különül el egyik kezelés sem, az összes paramétert figyelembe véve. A gazdaságilag legfontosabb paraméter, a friss tömeg esetében sem kaptunk egyértelmủ különbségeket. Látható azonban, hogy a legtöbb tényező esetében az alacsonyabb koncentráció kedvezőbb hatással volt a növények vegetatív fejlődésére.

\section{2. táblázat: A rukkola vegetatív paramétereinek átlagértékei élesztő oldatok} hatására. Az oszlopokon belül az eltérő betük szignifikáns különbséget jelölnek $(\mathbf{p}<\mathbf{0 , 0 5})$.

\begin{tabular}{|c|c|c|c|c|c|c|c|c|}
\hline $\begin{array}{l}\frac{\mathscr{d}}{\mathbb{N}} \\
\mathbb{0} \\
\mathbb{1}\end{array}$ & 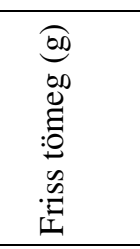 & 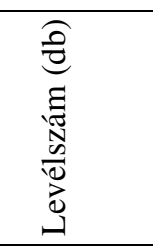 & 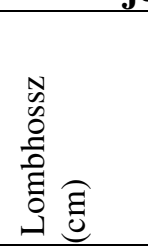 & 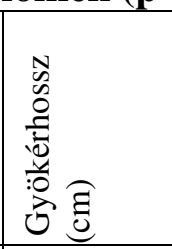 & 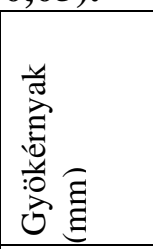 & 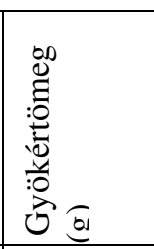 & 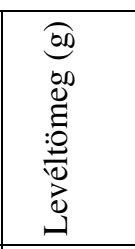 & 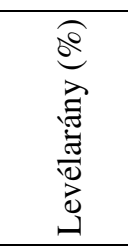 \\
\hline $0,1 \mathrm{~B}$ & $4.60 \mathrm{ab}$ & $6.98 \mathrm{a}$ & $13.38 \mathrm{ab}$ & $12.43 \mathrm{abc}$ & $2.13 \mathrm{abc}$ & $0.23 \mathrm{abc}$ & $4.35 \mathrm{ab}$ & $94.76 \mathrm{a}$ \\
\hline $0,1 \mathrm{~T}$ & $5.51 \mathrm{a}$ & $6.98 \mathrm{a}$ & $14.33 \mathrm{ab}$ & $13.16 \mathrm{ab}$ & $2.19 \mathrm{a}$ & $0.32 \mathrm{a}$ & $5.19 \mathrm{a}$ & $94.11 \mathrm{a}$ \\
\hline $0,1 \mathrm{~B} 3$ & $4.52 \mathrm{ab}$ & $6.70 \mathrm{ab}$ & $13.09 \mathrm{ab}$ & $11.81 \mathrm{c}$ & $2.03 \mathrm{abc}$ & $0.23 \mathrm{bc}$ & $4.29 \mathrm{ab}$ & $94.69 \mathrm{a}$ \\
\hline $0,1 \mathrm{~T} 3$ & $4.51 \mathrm{ab}$ & $6.70 \mathrm{ab}$ & $12.46 \mathrm{~b}$ & $11.83 \mathrm{bc}$ & $2.20 \mathrm{a}$ & $0.25 \mathrm{ab}$ & $4.27 \mathrm{ab}$ & $94.35 \mathrm{a}$ \\
\hline $1 \mathrm{~B}$ & $3.66 \mathrm{~b}$ & $6.03 \mathrm{bc}$ & $13.09 \mathrm{ab}$ & $12.23 \mathrm{abc}$ & $2.07 \mathrm{abc}$ & $0.21 \mathrm{bc}$ & $3.45 \mathrm{~b}$ & $94.21 \mathrm{a}$ \\
\hline $1 \mathrm{~T}$ & $3.52 \mathrm{~b}$ & $6.45 \mathrm{abc}$ & $13.65 \mathrm{ab}$ & $13.41 \mathrm{a}$ & $1.85 \mathrm{bc}$ & $0.18 \mathrm{bc}$ & $3.34 \mathrm{~b}$ & $94.59 \mathrm{a}$ \\
\hline $1 \mathrm{~B} 3$ & $3.69 \mathrm{~b}$ & $6.34 \mathrm{abc}$ & $14.22 \mathrm{a}$ & $12.83 \mathrm{abc}$ & $1.95 \mathrm{abc}$ & $0.19 \mathrm{bc}$ & $3.50 \mathrm{~b}$ & $94.48 \mathrm{a}$ \\
\hline $1 \mathrm{~T} 3$ & $3.35 \mathrm{~b}$ & $5.90 \mathrm{c}$ & $12.41 \mathrm{~b}$ & $12.21 \mathrm{abc}$ & $1.84 \mathrm{c}$ & $0.18 \mathrm{c}$ & $3.17 \mathrm{~b}$ & $94.59 \mathrm{a}$ \\
\hline K & $4.29 \mathrm{ab}$ & $6.18 \mathrm{bc}$ & $14.42 \mathrm{a}$ & $12.13 \mathrm{abc}$ & $2.14 \mathrm{ab}$ & $0.22 \mathrm{bc}$ & $4.07 \mathrm{ab}$ & $94.82 \mathrm{a}$ \\
\hline
\end{tabular}

Az eredmények könnyebb értelmezhetősége érdekében fökomponens analízist (PCA) végeztünk, és az eredményeket bi-ploton ábrázoltuk (1. ábra). A két első főkomponens 87,3\%-ban magyarázza az adatok varianciáját. Itt is elsősorban a legfontosabb paraméter, a friss tömeg viszonyát vizsgáltuk az alkalmazott kezelésekkel. A friss tömeg adatpontjához a 0,1T és 0,1B kezelés áll, majd a kontrollhoz képest közel azonos távolsággal a 0,1B3 és 0,1T3 kezelések vannak. Ez tovább erösíti a fenti feltételezést, miszerint a kisebb koncentráció kedvezőbb hatással van a friss tömegre, a levéltömegre, és a levélszámra, mint a magasabb koncentráció.

Adataink helyességét bizonyítja, hogy ezek a hasonló jellegü paraméterek viszonylag közel helyezkednek egymáshoz. Sem a varianciaanalízis, sem a PCA alapján nem lehet egyértelmüen rangsorolni a törzsgyüjteményi anyag és az instant élesztő hatását. 
1. ábra: A rukkola vegetatív paramétereinek ábrázolása PCA bi-ploton.

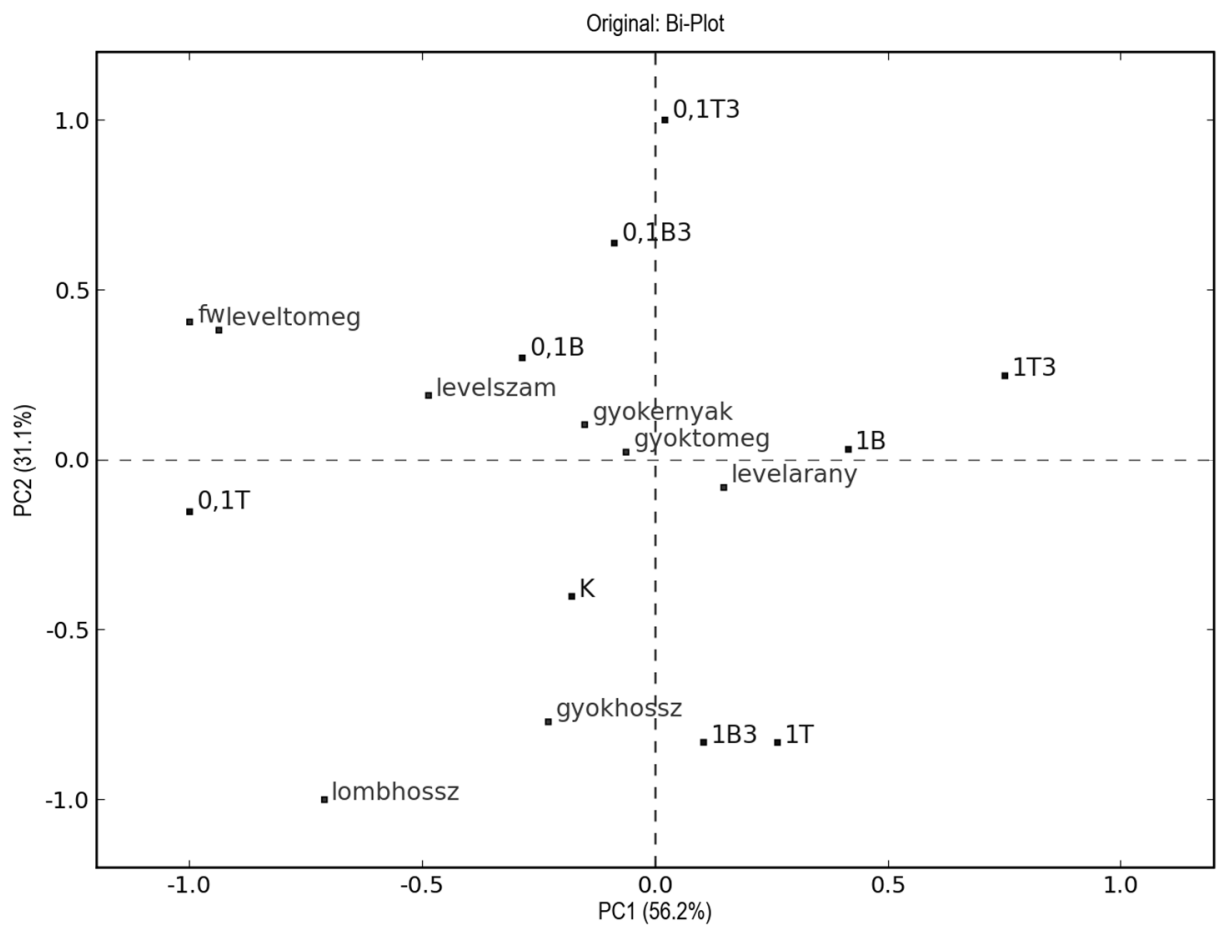

PanelCheck

A szakirodalomban található hasonló kutatások csak esetenként térnek ki a koncentráció, mint tényező vizsgálatára (Csambalik és Tóbiás, 2019). Fejessalátán végzett kísérletek esetében a magasabb koncentráció kedvezőbb hatással volt a friss tömegre (Farrag et al., 2016). Feltételezzük, hogy a szakirodalommal ellentétes eredményeink oka a hüvös öszi időjárás is lehetett.

\section{Következtetések, összegzés, záró megjegyzések, záró gondolatok}

Az élesztő szuszpenziók vegetatív növekedésre gyakorolt kedvező hatását számos kutatás igazolja. Egy éves kíséreltünkben rukkola tesztnövényen végeztünk kezeléseket. Eredményeink az alacsonyabb koncentráció kedvezőbb hatását mutatták. Következtetéseink igazolására további vizsgálatok beállítását tervezzük.

\section{Köszönetnyilvánítás}

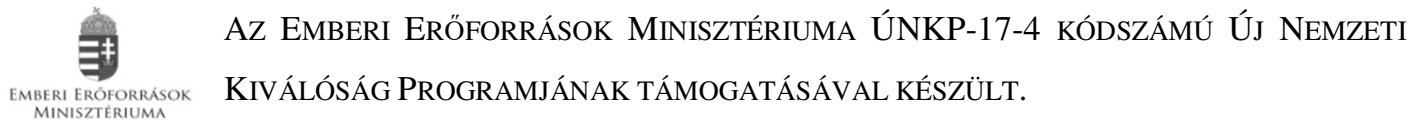

\section{Irodalomjegyzék}

Ahmed, A.A., Abd El-Baky, M.M.H., Zaki, M.F., Faten S., Abd El-Aal, M.M. (2011): Effect of Foliar Application of Active Yeast Extract and Zinc on Growth, Yield and Quality of Potato Plant (Solanum tuberosum L.). Journal of Applied Sciences Research, 7 (12):2479-2488. 
Barnett, J.A., Payne, R.W., Yarrow, D. (1990): Yeast Characteristics and Identification, second ed. Press, Cambridge Univ., London, UK, 1012 p.

El-Desouky, S.A., F.H. Ismaeil, A.L. Wanas, E.S., Fathy, L., Abd El-Aal, M.M. (2011): Effect of yeast extract, amino acids and citric acid on physioanatomical aspects and productivity of tomato plants grown in late summer season. Minufiya J. Agric. Res., 36 (4):859-884.

Farrag D, El-Dein O, Khafagy I (2016): Impact of spraying with Saccharomyces cerevisiae and some commercial nutrients on lettuce plant (Lactuca sativa L.) productivity and prevention of some insect pests. Int J Pl Soil Sci 11:1-11.

Fathy, S.L., Farid, S. (1996): Effect of some chemical treatments, yeast preparation and Royal Jelly on some vegetable crops growing in late summer season to induce their ability towards better thermal tolerance. J. Agric. Sci. Mansoura Univ., 25 (4):2215-2249.

Fawzy ZF (2010): Increasing productivity of head lettuce by foliar spraying of some bio and organic compounds. Mesopotamia J Agric 38:Supplement 1.

Gawlik-Dziki, U., Świeca, M., Dziki, D., Sugier, D. (2013): Improvement of nutraceutical value of broccoli sprouts by natural elicitors. Acta Scientiarum Polonorum, Hortorum Cultus, 12 (1):129140.

Ghoname, A.A, El-Nemr, M.A.A., Abdel-Mawgoud, M.R., El-Tohamy, W.A. (2010): Enhancement of Sweet Pepper Crop Growth and Production by Application of Biological, Organic and Nutritional Solutions. Research Journal of Agriculture and Biological Sciences, 6 (3):349-355.

Hammad, S.A.R. (2008): Physiological and anatomical studies on drought tolerance of pea plants by application of some natural extracts. Ann. Agric. Sci., Ain Shams Univ., Cairo 53 (2):285-305.

Nagodawithana, W.T. (1991): Yeast Technology. Universal foods corporation Milwaukee, Wisconsin. Van Nostrand Reinhold, New York, 273 p.

Sarhan, T., Abdullah, O.K. (2010): Effect of Azotobacter Inoculation, Dry Bread Yeast Suspension and Varying Levels of Urea on Growth of Potato Cv. Desiree. html/www.tropentage.de/2010/abstracts/full/628.

Złotek U, Świeca M (2016): Elicitation effect of Saccharomyces cerevisiae yeast extract on main health-promoting compounds and antioxidant and anti-inflammatory potential of butter lettuce (Lactuca sativa L.). J Sci Food Agric 96:2565-2572. 